\title{
Sedimentology and ichnology of the Robbedale Formation (Lower Cretaceous), Bornholm, Denmark
}

\author{
JAN KRESTEN NIELSEN, KIM STEN HANSEN \& LARS SIMONSEN
}

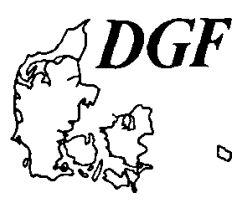

\begin{abstract}
Nielsen, J. K., Hansen, K. S. \& Simonsen, L.: Sedimentology and ichnology of the Robbedale Formation (Lower Cretaceous), Bomholm, Denmark. Bulletin of the Geological Society of Denmark, Vol. 43, pp. 115-131. Copenhagen, 1996-12-05. https://doi.org/10.37570/bgsd-1996-43-12
\end{abstract}

\begin{abstract}
An exposure of the Lower Cretaceous Robbedale Formation adjacent to the Rønne Golf Course, Bomholm, has permitted a more detailed study of the trace fossils than has been made hitherto. A lithofacies analysis indicates that the sediments were deposited on the lower to upper shore face in a wave dominated barred coastal environment. The following trace fossils are present: Conichnus conosinus isp. n., Cylindrichnus isp., Ophiomorpha nodosa, Skolithos linearis, Teichichnus rectus, Thalassinoides suevicus forms 1 and 2 . These seven trace fossils are contained in nine ichnofabrics. The ichnofabrics are closely related to sedimentary facies and suggest a shallow marine sedimentary environment. The abiotic factors, sediment stability and grain size, probably affected the distribution of ichnofabrics by controlling the occurrence of trace makers and their behaviour. Associated with Ophiomorpha nodosa at one horizon are a series of trace fossils that may be interpreted as fodinichnial structures. They somewhat resemble "rayholes". The available nomenclature for such structures is discussed and the name Conichnus conosinus isp. $\mathrm{n}$. is proposed.
\end{abstract}

Key words: Sedimentology, ichnology, Robbedale Formation, Lower Cretaceous, Bomholm, Denmark.

J. K. Nielsen and K. S. Hansen, Department of Historical Geology \& Palaeontology, Geological Institute, University of Copenhagen, Øster Voldgade 10, 1350 Copenhagen K, Denmark; L. Simonsen, Vingen 15, 3140 Ålsgårde, Denmark. 15th May, 1996.

The Berriasian (Lower Cretaceous) Robbedale Formation of Bornholm, Denmark consists of uncemented fine-grained sand (Østerborg Member) and medium to coarse sand and gravels (Langbjerg Member) (Gravesen 1982). Depositional environments fluctuated between decidedly nonmarine and marine conditions (Gravesen, Rolle \& Surlyk 1982). Trace fossils are abundant and especially well preserved in the Østerborg Member and were first described by Gry (1968) and Jux \& Strauch (1968). They have been mentioned and illustrated (i.e. Gravesen et. al. 1982; Noe-Nygaard \& Surlyk 1988), but an up-to-date appraisal is overdue. A new Conichnus isp. is proposed in the present paper. Inland exposures of the formation are deteriorating rapidly owing to abandonment of the quarries. However, the appearance of a new exposure adjacent to the Rønne Golf Course (pit II) (Fig.
1) was taken as an opportunity to make an ichnological study of a part of the Robbedale Formation.

\section{Stratigraphy and palaeogeography}

Bomholm is situated in the Baltic Sea south of Sweden within the Tomquist-Sorgenfrei Lineament and is strongly block-faulted (Gry 1968). Down faulting of the blocks as a result of Late Kimmerian extensional tectonics brought about the deposition of the Nyker Group (Ziegler 1987; Gravesen et al. 1982).

Sedimentation was controlled by tectonics, changes in sea-level (eustasy) and fluctuations of climate (Gry 1968; Gravesen et al. 1982). Fault-control on sedimentation has been proposed for the Nyker Group by 


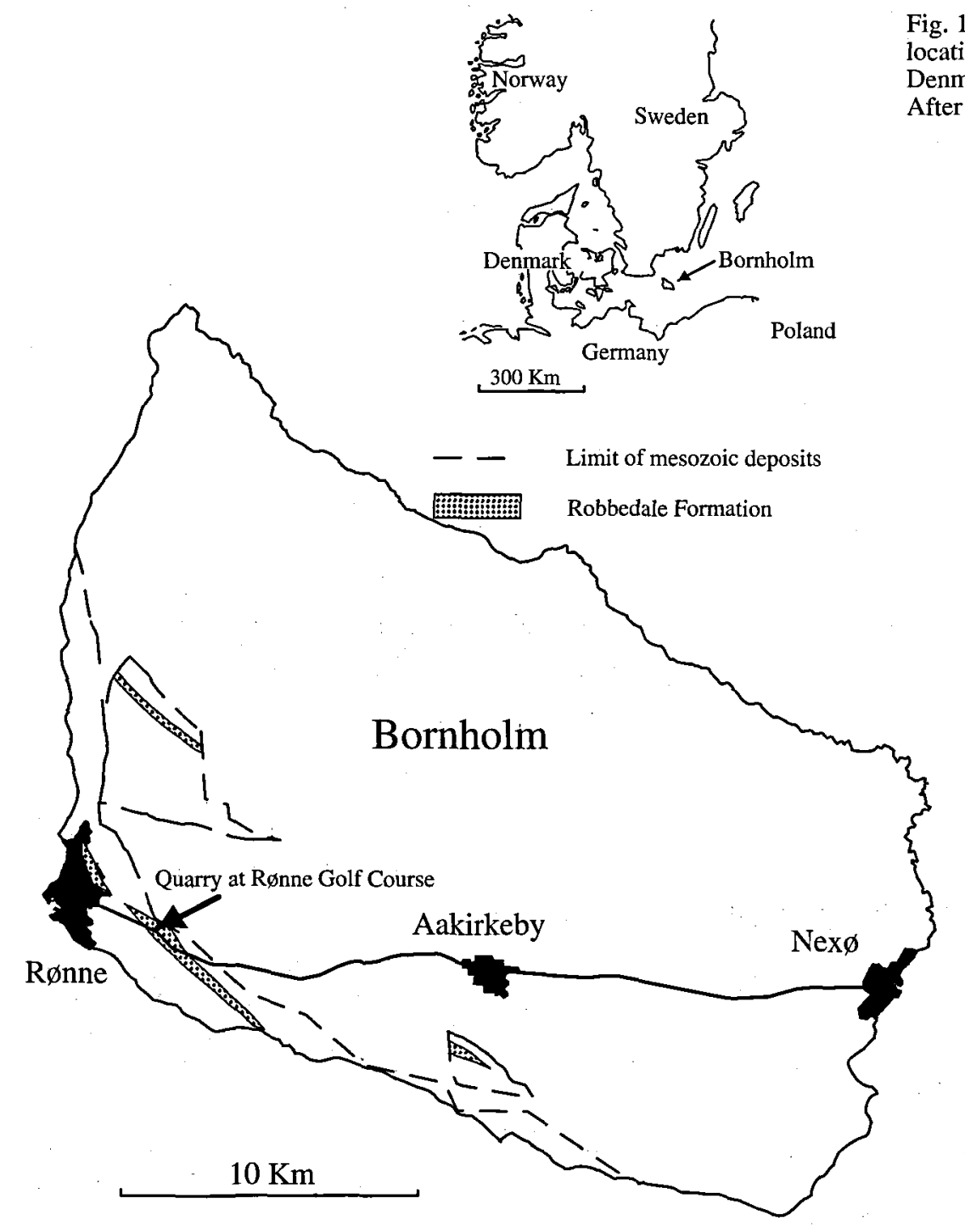

Fig. 1. Map showing geographical location of the island Bornholm, Denmark and the studied locality After Gravesen et al. (1982).

Gravesen et al. (1982) and Noe-Nygaard \& Surlyk (1988). The Nyker Group comprises a transgressive to regressive phase. At the time of deposition (Berriasian), Bornholm was situated at the edge of a narrow seaway connecting the Danish Embayment and the Polish Trough, i.e. a boreal North Sea and the Tethyan Sea (Doré, 1991). Later tectonic inversion phases in Late Cretaceous and Neogene seem to be responsible for the present structural configuration. The uplift during the inversion phases is thought to be more than 1 $\mathrm{km}$ in the Tornquist-Sorgenfrei lineament (Japsen 1993).

The Nyker Group, which unconformably overlies the Middle Jurassic Bagå Formation and is itself unconformably overlain by Upper Cretaceous marine sediments of the Arnager Greensand Formation (Gry 1968; Gravesen et al. 1982), has traditionally been described as composed of a lower clay-rich limnic and fluviatile Rabekke Formation followed by the Robbedale Formation. The Robbedale Formation consists of a lower Østerborg Member deposited during transgression and an upper Langbjerg Member which, together with the superjacent Jydegård Formation, was deposited during regression (Gravesen 1982). The Jydegård Formation is a clay- and sand-dominated, lagoonal and fluviatile sediment (Gravesen et al. 1982; NoeNygaard, Surlyk \& Piasecki 1987; Noe-Nygaard \& Surlyk 1988).

Direct evidence of the age of the Robbedale Formation is not available, but the Jydegård Formation has been dated as Late Berriasian to Valanginian using ostracodes and dinoflagellates (Christensen 1974; Surlyk 1980; Piasecki 1984). The upper part of the Rabekke Formation also has yielded ostracodes, which 
Fig. 2. Conceptual stratigraphic scheme including Rabekke Formation, Robbedale and Langbjerg Member) and Jydegård Formation. Sequence stratigraphic notations: HST, highstand system tract; SB, transgressive surface. Formation (Østerborg Member sequence boundary; TS,

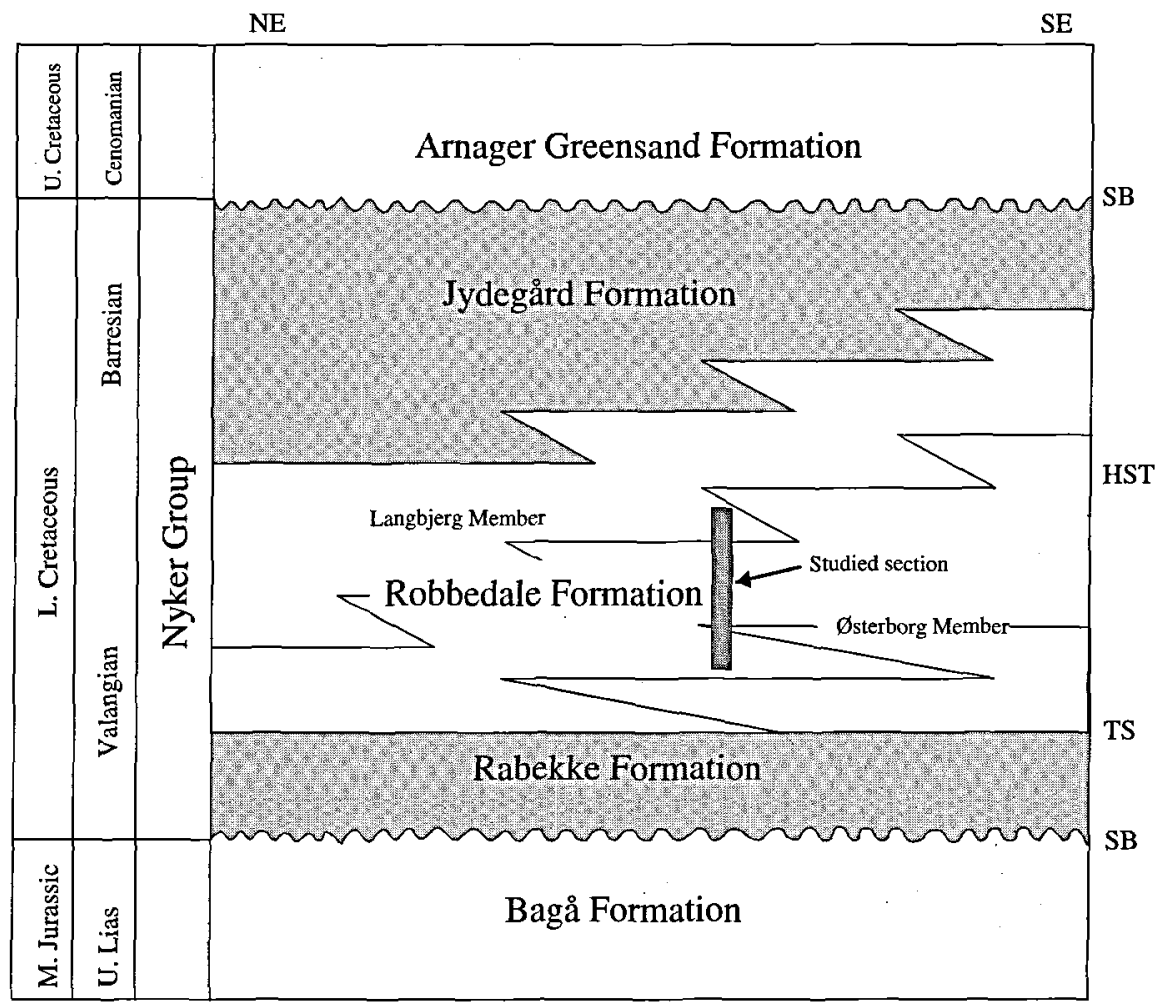

\section{Sedimentology}

stensen 1974).

A new sequence stratigraphic approach is attempted here, in which the Rabekke Formation is regressive and constitutes the lowstand system tract. These deposits are followed by a transgression and deposition of prograding to aggrading and normal regressive sediments of the Robbedale and Jydegård Formation during the highstand system tract (Fig. 2). From seismic lines and samples from the sea floor just south of Bornholm it has been shown that there apparently is no evidence of relatively deep marine sedimentation above the Rabekke Formation. Instead there is a direct transition from the Rabekke Formation to the Robbedale Formation (Fredningsstyrelsen 1986). This could be due either to erosion or that the Nyker Group was developed on a basement high where deeper marine conditions were never reached. The transgression seems to have regional extension. In Scania (Sweden) there is a similar paralic succession in Lower Cretaceous, but no hiati or erosional surfaces are mentioned (Norling 1981). The model presented here suggests that the change in grainsize from $\emptyset_{\text {sterborg Member to }}$ Langbjerg Member is merely a change in environment during a period of prograding to aggrading conditions and not a change from transgressive to regressive conditions (Fig. 2). During continuing progradation under normal regressive conditions, lagoonal and fluvial sedimentation of the Jydegård Formation overlies the coastal environments of the Robbedale Formation.
The sedimentology of the Robbedale Formation has been discussed by Gravesen $(1982,1986)$ and Gravesen et al. (1982), but the section described here has not been previously available. The two members are mainly distinguished on the basis of grain size. The $\emptyset$ sterborg Member is silty fine-grained sand and Langbjerg Member is medium to coarse sand and grav(1982) also included plant material and ichnology. At the Rønne Golf-course the transition from Østerborg Member to Langbjerg Member is exposed (Figs 3 \& 4). No shelly fossils are preserved in the sediment.

\section{Units $\mathrm{A}$ and $\mathrm{E}$}

Description: Units A \& $\mathrm{E}$ both consist of white, finegrained sand including some lenses or layers of fine to medium-grained sand. The sand is well-sorted, containing subangular to well-rounded grains. The smallest grains are the most rounded. The only primary structures are plane layering and the above-mentioned lenses of coarser material. The plane layering is defined by thin drapes of mica. Bioturbation increases from sparse to common through unit $A$. Bioturbation varies between common and sparse through unit $\mathrm{E}$.

Interpretation: These two units are grouped as facies 1. In facies 1 physical reworking probably was a the els. In the definition of the members, Gravesen et al. 


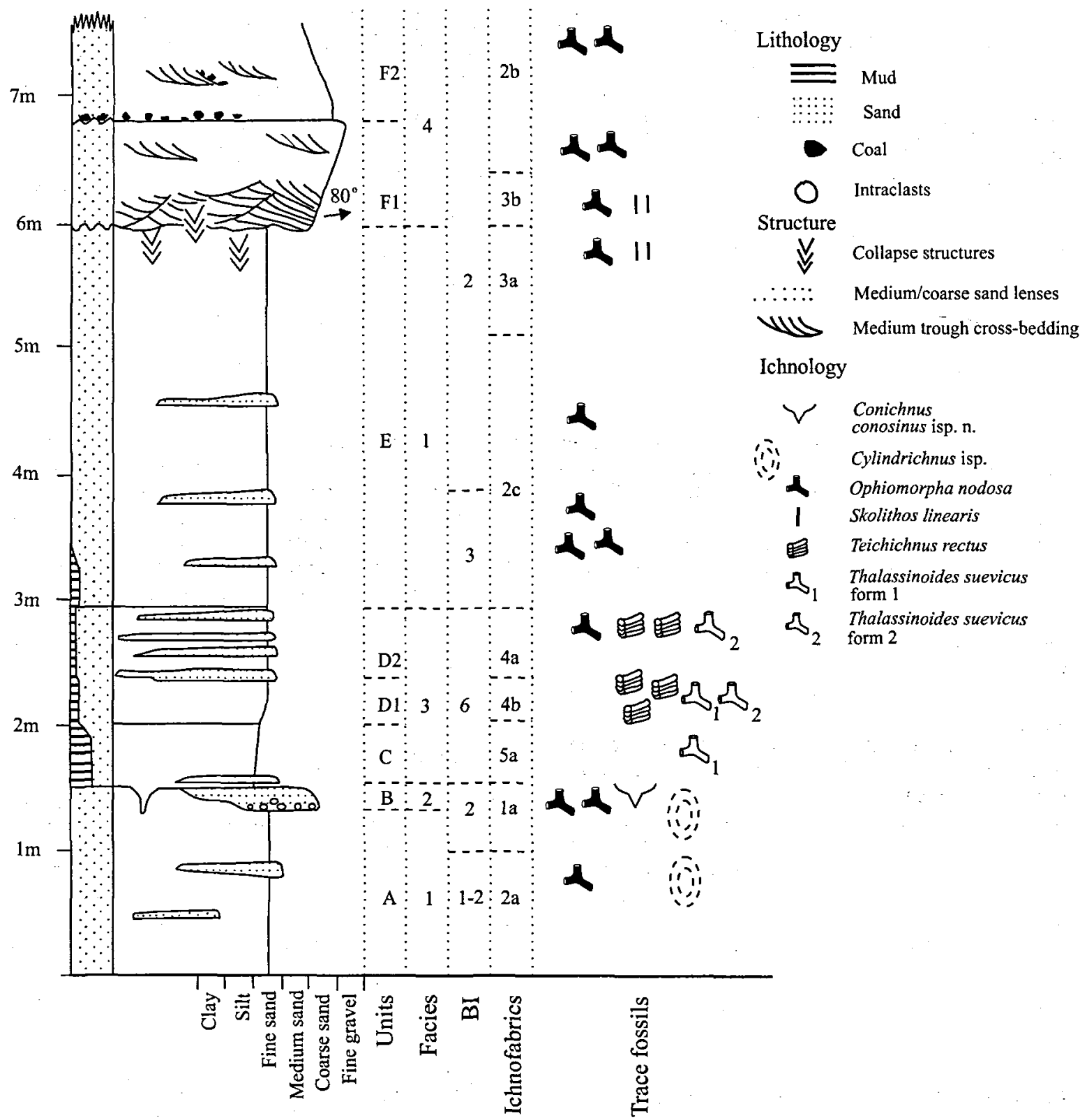

Fig. 3. Log illustrating the examined part of the Robbedale Formation. The relative abundance of each ichnotaxon is indicated by the number of symbols (sparse, common, abundant). Bioturbation index (BI) after Taylor \& Goldring (1993). 


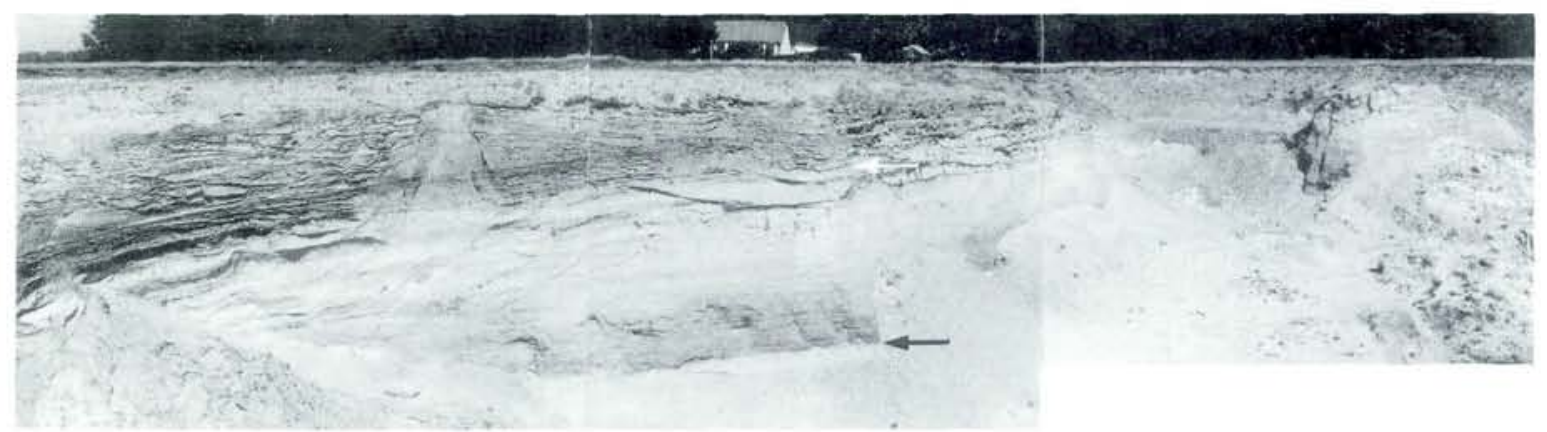

Fig. 4. Overview of the Rønne Golf Course pit at the time of field work. The quarry is still in use. The lower arrow indicates boundary between unit $\mathrm{A}$ and $\mathrm{B} / \mathrm{C}$. The upper arrow indicates boundary between $\mathrm{E}$ and $\mathrm{Fl}$. The distance between the arrows is $4.5 \mathrm{~m}$.

dominant factor. During storms, waves may generate fluidized sediment grain flows in which mica grains tend to concentrate at the base (Inman, Ewing \& Corliss 1966). This would explain the mica-layering.

The coarser lenses are considered to be due to storms transporting sediment as offshore flows generated by hydrostatic pressure (Allen 1982; Swift \& Thorne 1991). Following the storm, long-term swell reworks much of this sediment and returns the coarser sand landward (Komar 1976: 320). The lenses and beds of coarser (medium-grained granular) sand are interpreted as a post-storm lag.

There are no hummocky cross stratification or small scale ripples in the sediment. These structures would be present in the upper part of a fully developed stormsequence, but because of reworking of the sediment, both physically and by bioturbation, these structures have a low potential for preservation (Clifton 1981; Miller \& Myrick 1992). The facies is interpreted as representing the outer slope of bars, the sediment having originated from bars and been redeposited by waves.

\section{Unit B}

Description: The boundary separating unit A from C is erosive and the contact is not crossed by trace fossils. In the eastern part of the sand pit, the boundary is only weakly erosive. Erosive scours into the top of unit $\mathrm{A}$ at the boundary $\mathrm{A} / \mathrm{C}$ are filled with yellow sand. This fill is designated unit B. The scour-fills fine upwards and are cross-bedded. The bottoms of the scours contain coarse sand and clasts representing reworked fragments of trace fossils (Ophiomorpha nodosa) (Fig. 5). No trace fossils have been observed in situ. In some places there is a rapid transition from sand-filled scours to a thin fine-grained sand layer $1-2 \mathrm{~cm}$ thick. Locally a $1 \mathrm{~cm}$ thick bed of greenish mud separates the scours and the overlying fine sand layer. The scours and the fine sand layer are not consistent throughout the exposure, but disappear to the northeast.
Interpretation: Deposition of sand of facies 1 was interrupted by a deepening of water. Before fine material was deposited, storm conditions were able to erode the sediment and caused scouring. Only coarser material was deposited as a lag deposit (Nummedal \& Swift 1987). Later a weaker storm may have generated the thin sand layer. These sand layers or transgressive lag comprise facies 2 . The change in sea level may have been caused by tectonics or by a lateral change in environment, where the beach was starved of sediment.

\section{Units C, D1 and D2}

Description: These three units together coarsen upwards and define facies 3 . Unit $C$ consists of $35 \mathrm{~cm}$ of organic-rich sandy clay and silt having a greenish colour. Unit D1 consists of $45 \mathrm{~cm}$ of silty fine-grained sand having a light greyish colour. Both units are totally bioturbated. The transition from unit D1 to unit D2 is gradual, and unit D2 consists of the same silty fine-grained sand as in unit D1. Unit D2, in contrast, also contains four layers approximately $5 \mathrm{~cm}$ thick of

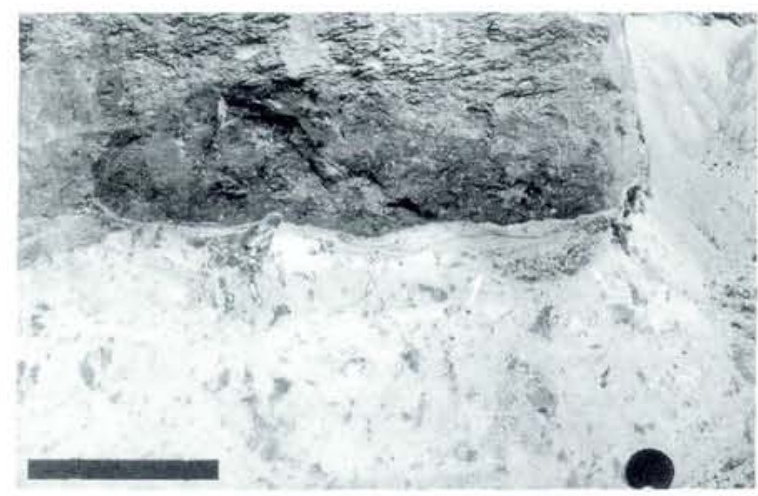

Fig. 5. Scour with fill containing clasts of Ophiomorpha nodosa, unit B. Scale $20 \mathrm{~cm}$. Photograph taken by R. G. Bromley. 
well sorted, normal graded, medium to fine-grained sand. The total thickness of unit D2 is $60 \mathrm{~cm}$. There is no distinct boundary between units D2 and E.

Interpretation: Units C, D1 \& D2 (facies 3) are thought to have been deposited in relatively deeper water. The phase of deepening induced a pause in sand sedimentation and a relative increase in clay deposition. Slowly the shoreline prograded and coarser material and storm induced sand stringers in unit D2 were deposited.

\section{Units F1 and F2}

Description: Units F1 and F2 overlie unit $\mathrm{E}$ and consist of moderately sorted, subangular, medium to coarse, greyish sand. The units have trough-cross-bedding alternating with intervals lacking any visible structures. The height of the cross-bedding sets is approximately $10-20 \mathrm{~cm}$ and the palaeoflow direction has been measured as approximately $40^{\circ}$. The cross-bedding seems to be most intense in the lower part of unit F1, although visibility in the unlithified, pure white sand is poor. In unit F1 there are thin layers of coal in connection with the set-boundaries. More often, only scattered clasts of coal, less than $1 \mathrm{~cm}$ in size, are found. The density of coal-fragments increases upward through unit F1. The top of unit F1 is overlain by an interrupted coal layer up to $5 \mathrm{~cm}$ thick. The unit above this coal layer is $F 2$, which resembles unit F1. In unit $\mathrm{F} 2$, however, the density of coal fragments decreases upwards. The unit has been disturbed by ice movement during the Quaternary, and therefore was not examined thoroughly.

Interpretation: Units $\mathrm{F} 1$ and $\mathrm{F} 2$ are interpreted as representing a rip channel and longshore trough. This corresponds with the abrupt increase in grain size and the erosive character of the bottom of unit F1. The most typical structures in longshore trough facies consist of relatively coarse sand and gravel containing longshoredipping medium-scale trough cross-bedding overlain by finer-grained onshore-dipping medium and smallscale cross-bedding. Rip-channel facies typically consist of offshore-dipping trough cross-bedding and tabular cross-bedding (Hunter, Clifton \& Phillips 1979). None of the bar facies is preserved, as it would be eroded by the trough and rip-channel as these migrated seaward. Units $F 1$ and $F 2$ are grouped together as facies 4 and represent a prograding upper shoreface environment, as expressed by the topographically low structures of rip channel and longshore trough.

The four facies $(1,2,3$ and 4) are grouped together as one facies association, deposited on the foreshore/ shoreface in a wave dominated barred coastal environment. The four facies probably represent one prograding succession interrupted by a minor transgression giving the scour and fine grained association. The boundary between units $\mathrm{E}$ and $\mathrm{F}$ is the boundary between Østerborg Member and Langbjerg Member. The change in grainsize is interpreted as an expression of changing facies in a shore environment under nearly constant basin subsidence and not a change from transgressive to regressive conditions.

\section{Ichnology}

The units in the examined outcrop are all partly or totally bioturbated. The following ichnotaxa are represented: Conichnus conosinus isp. n., Cylindrichnus isp., Ophiomorpha nodosa, Skolithos linearis, Teichichnus rectus and Thalassinoides suevicus forms 1 and 2, each of which is described below.

Because the sediments are not cemented, it is impossible to collect intact samples without the use of fixatives. At the slightest touch the biogenic structures tend to collapse. The outcrop surface is exposed to natural wind-generated sand-blasting, which increases the visibility and three-dimensional exposure of the structures. The interaction between variations in texture, grainsize, colour and sand-blasting allow the discrimination and study of the trace fossils.

\section{Sampling}

A sample of Conichnus conosinus isp. $\mathrm{n}$. was taken by smoothing a vertical wall showing a section of a specimen. The surface was sprayed with glue (3M Photo Mount). Immediately after this the surface was covered with fabric. After the glue had hardened a thin layer of sediment attached to the fabric could be removed. Finally the sample was sprayed with laquer ( $3 M$ Spray Fix) to provide extra binding. A similar method was described by Farrow (1975).

\section{Ichnological descriptions}

Conichnus conosinus isp. $\mathbf{n}$.

Type locality: The type locality for this ichnospecies is the inland quarry at the eastern margin of the Rønne Golf Course, Bornholm, Denmark, adjacent to the road from Rønne to Aakirkeby (Fig. 1). The trace fossils

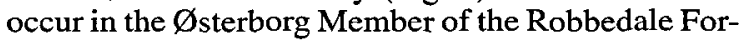
mation, Lower Cretaceous (Gravesen et al. 1982).

Type horizon: Emplaced in the uppermost part of unit $\mathrm{A}$ at the boundary to unit $\mathrm{C}$.

Holotype: Glue-laquer-peel (Fig. 6), Geological Museum of Copenhagen, Denmark, MGUH 22180.

Etymology: "cono-" (Latin conus) refers to the conical component of the trace fossil. "-sinus" (Latin sinum) refers to the dish-shaped component of the trace fossil. 


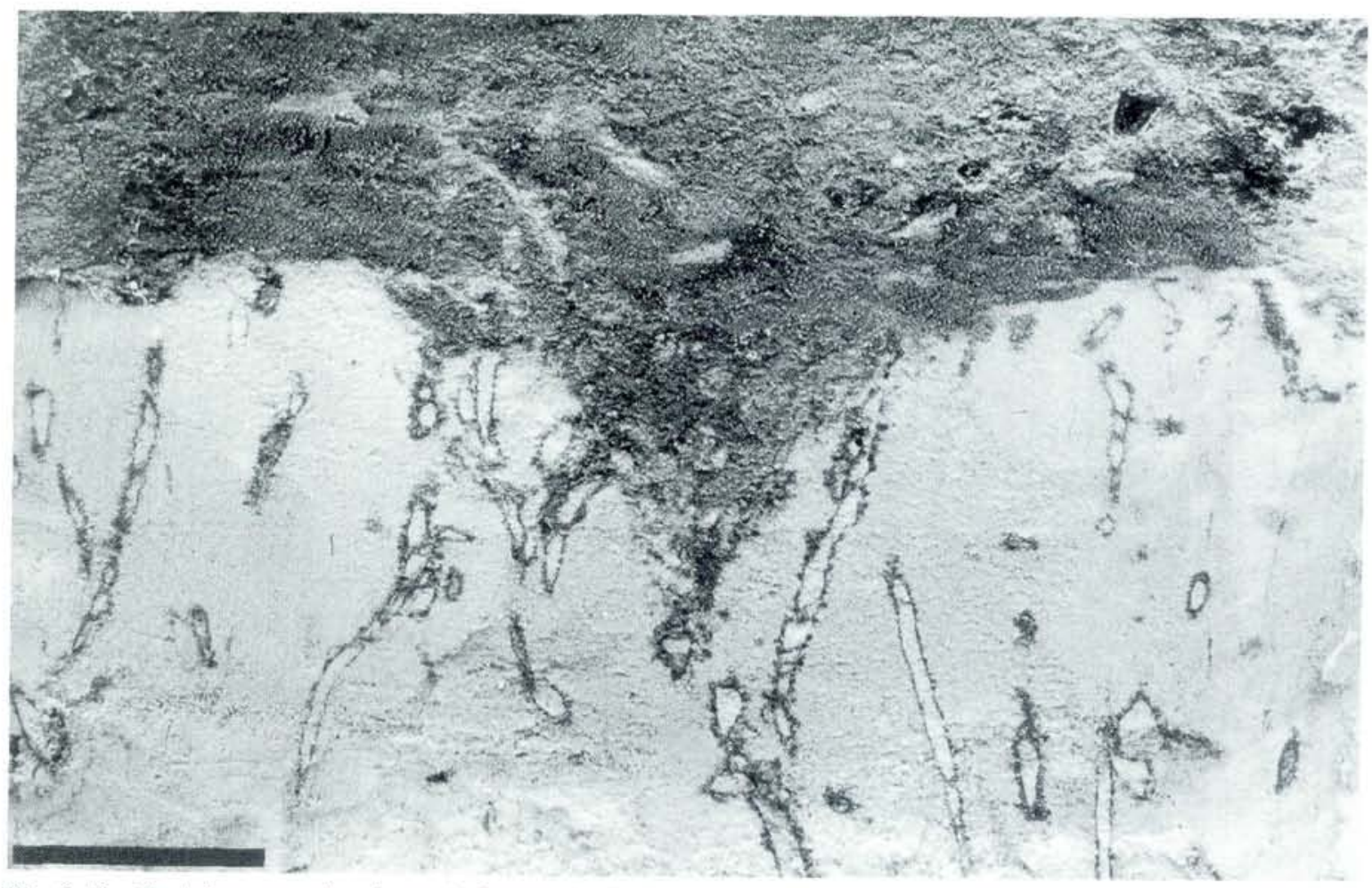

Fig. 6. The Conichnus conosinus isp. n. holotype (Geological Museum, Copenhagen, MGUH 22180) in the field. Scale 10 $\mathrm{cm}$.

Diagnosis: A Conichnus that consists of sub-conical depressions having two main components: an upper, broad, dish-shaped depression and a steeply inclined cone in the central part of the trace fossil. The dishshaped upper depression tends to be oval in form.

Morphology: The structure has two main components. An upper, broad, dish-shaped depression abruptly changes to a steeply inclined cone in the central part of the trace (Figs $6 \& 7$ ). At the bottom of the cone there are commonly one or several truncated shafts of Ophiomorpha nodosa (Fig. 8A). The dish and the upper parts of the cone are generally filled with mottled to weakly stratified sediment, whilst the bottom of the cone is filled with structureless sand. Successive vertical sections through the trace reveal that the dishshaped upper depression tends to be prolonged as an oval in one direction, giving the trace fossil a bilateral symmetry. At the perimeter of the dish a minor ridge occurs in some examples.

The diameter of the dish ranges from 18 to $27 \mathrm{~cm}$ and the depth varies from 1 to $3.5 \mathrm{~cm}$. The diameter of the cone ranges from 10 to $17 \mathrm{~cm}$ and the total depth of the trace varies from 9 to $15 \mathrm{~cm}$.

Discussion: Evidence strongly suggests a biotic origin of the structure. The structure is in sharp contact with the sediment in which it is emplaced (unit A) (cf.
Kamola 1984: 535, fig. 18). The internal fill of Ophiomorpha nodosa below Conichnus conosinus isp. $\mathrm{n}$. consists totally of white sand. There is no sediment similar to unit C. The fill of Conichnus conosinus isp. n. generally does not exhibit any internal primary sedimentary structures, except in the upper part. Compared with pot casts (potholes) the outline of Conichnus conosinus isp. $\mathrm{n}$. is very regular and lacks spiraling groove marks (Knaust \& Langbein 1995). There is no

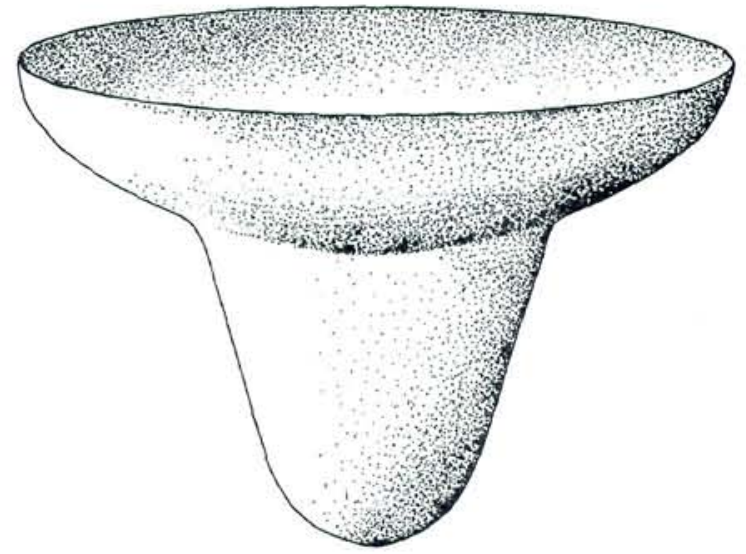

Fig. 7. Drawing of Conichnus conosinus isp. n. Not to scale. 

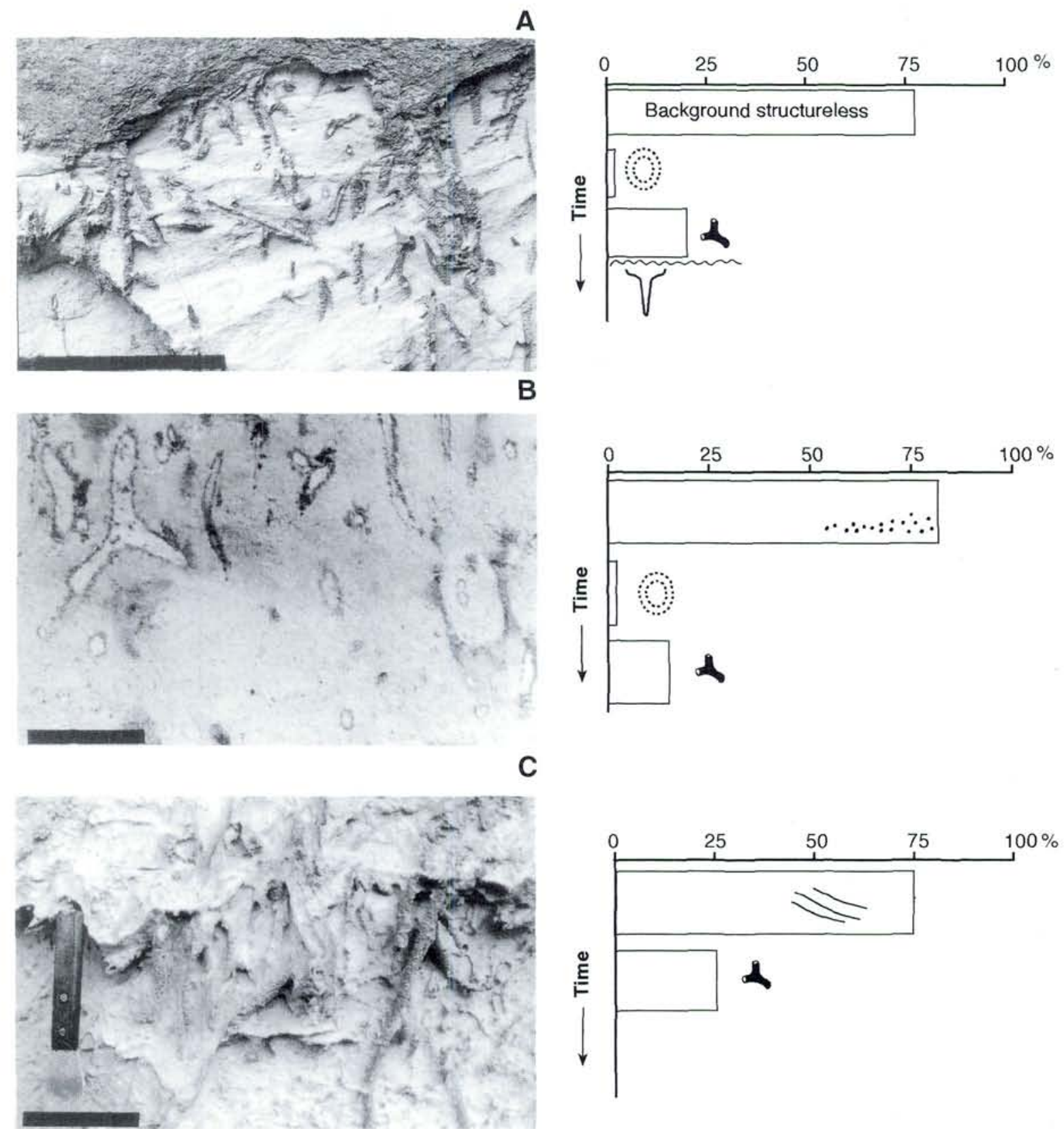

Fig. 8. Photographs of ichnofabrics and time sequence diagrams. The latter showing degree of bioturbation related to ichnotaxa and time. Percentage values are approximate. Legend as in Fig. 3. A: Ichnofabric la with specimens of Conichnus conosinus isp. $\mathrm{n}$. at the A/C boundary. Scale $20 \mathrm{~cm}$. B: Ichnofabric $2 \mathrm{a}$, lower part of unit $\mathrm{A}$. The small dots are concretions and stains of iron oxides. Scale $5 \mathrm{~cm}$; : Ichnofabric $2 \mathrm{~b}$, upper part of unit F1 and unit F2. Scale $10 \mathrm{~cm}$. 
evidence indicating deformation after formation of the traces. In units $A$ and $C$ no slump structures or water escape structures have been observed. It is thus concluded that the structure is a trace fossil.

The morphology of this trace fossil poses some ichnotaxonomical problems, combining characteristics of two different groups of trace fossils in one structure. Furthermore, its ethological interpretation does not follow that normally implied by those two groups.

The dish-shaped structure at the upper part of the trace fossil resembles examples described elsewhere as depressions produced by fish (Cook 1971; Willers 1981; Johnson, Halfman, Busch \& Flood 1984). Such structures formed the basis of the ichnogenus Piscichnus as described by Feibel (1987).

The lower part of the Robbedale structure, however, resembles the conical trace fossil Conichnus as erected by Myannil (1966) and emended by Pemberton, Frey \& Bromley (1988). There is an abrupt break in morphology between the two parts of the trace fossil, yet the two parts clearly represent a constructional unit.

It should be mentioned that Gregory (1991) has emended Piscichnus markedly so as to include deep, steep, plug-shaped trace fossils which he attributed to feeding activities of rays. This emended version has been followed by Ekdale \& Lewis (1991). Those authors' trace fossils, however, more closely are allied to the morphology of Bergaueria, as discussed by Pemberton et al. (1988), and Kulindrichnus and do not resemble the Robbedale material. Because the trace fossil in the Robbedale Formation is dominated by the deep conical part, it is referred here to Conichnus.

Conichnus conosinus isp. $\mathrm{n}$. is distinct from Conichnus conicus Myannil 1966 and Conichnus papillatus Myannil 1966 (cf. Pemberton et al. 1988) by having the dish component. In addition, the Conichnus conosinus isp. n. lacks a papillate protuberance.

Interpretation: As Ophiomorpha nodosa occurs in relatively high concentrations immediately below specimens of the Conichnus conosinus isp. n., the latter are clearly genetically associated with them. The Conichnus conosinus isp. $\mathrm{n}$. may thus be interpreted as the work of an animal preying upon the Ophiomorpha nodosa-maker. As such, the Conichnus conosinus isp. n. represents a praedichnion. But this interpretation does not clarify for what purpose the predator preyed upon Ophiomorpha nodosa filled with white sand. The Ophiomorpha nodosa surely was abandoned before formation of Conichnus conosinus isp. $\mathbf{n}$.

Another interpretation may be suggested. For example Karplus, Szlep \& Tsurnamal (1974) and Bromley (1990: 95) mentioned examples of endobenthic symbiosis. Perhaps the occurrence of Conichnus conosinus isp. n. with Ophiomorpha nodosa below is an example of a similar habit, namely interaction between an epibenthic tracemaker and an endobenthic tracemaker respectively. As no constrictive apertures of Ophiomorpha nodosa exist in contact with Conichnus conosinus isp. $\mathrm{n}$. and again considering the presence of an infill of white sand in Ophiomorpha nodosa there is no evidence supporting this explanation.

For example Mauviel, Juniper \& Sibuet (1987) and Bromley (1990: 45-46, 48, 268, figs 4.12, 4.14; 1996: $47-51$, 344, figs $3.14,3.16,3.17$ ) demonstrated the concept of funnel feeding with recent examples involving endobenthic animals. By means of a funnel-shaped burrow aperture the animal traps detritus. Conichnus conosinus isp. n. may be interpreted in a similar ethological way. As such, the lower component was inhibited by the tracemaker and the upper main component functioned as a trap. But this does not explain the occurrence of Conichnus conosinus isp. n. above relatively high concentrations of Ophiomorpha nodosa.

Alternatively, Conichnus conosinus isp. $\mathbf{n}$. can be interpreted as a feeding trace reflecting "open-pit mining". The tracemaker exploited a particular part of the substrate for food, maybe to gather organic material incorporated in wall-linings of the Ophiomorpha nodosa. During time of "mining" the tracemaker occupied the depression. Following this interpretation, Conichnus conosinus isp. $n$. can be ethologically classified as a fodinichnion (combination of feeding and dwelling).

In summary, Conichnus conosinus isp. n. most probably represents a fodinichnion. The biological nature of the tracemaker is not known.

\section{Cylindrichnus isp.}

These trace fossils, preserved in full relief, are slightly curved and obliquely oriented. The traces have an elliptical outline in cross section (Fig. 8B). The diameter is generally around $2.5 \mathrm{~cm}$. The exterior wall is composed of mutiple layers of darker and lighter coloured sediment, a feature that was also observed in this ichnogenus by McCarthy (1979), Archer (1984) and Howard \& Frey (1984). They are here assigned to Cylindrichnus Toots in Howard 1966.

\section{Ophiomorpha nodosa Nilsson in Lundgren 1891}

These trace fossils (Figs $8 \&$ 9) have external diameters from 5-13 mm and internal diameters from 4-13 $\mathrm{mm}$. These dimensions are relatively small for the ichnotaxon (cf. Frey, Howard \& Pryor 1978). The thickness of wall- and roof-lining varies from ca. 1 $\mathrm{mm}$ to extremely thin. In the Robbedale Formation somewhat larger dimensions, i.e. external diameters of 10-20 mm, were reported by Gry (1968) and Jux \& Strauch (1968).

The general configuration of the palaeoburrows comprises vertical shafts showing branching. We have been able to trace individual trace fossils for a maximum length of $67 \mathrm{~cm}$, but there is indirect evidence of substantially greater lengths. If palaeoburrows in unit $\mathrm{A}$ were filled with sediment derived from Unit $\mathrm{E}$, it would indicate a minimum length of $1.5 \mathrm{~m}$. Gry (1968) observed that the nearly vertical shafts could reach lengths of at least $1 \mathrm{~m}$ and Bromley (1979) reported shafts to 
A
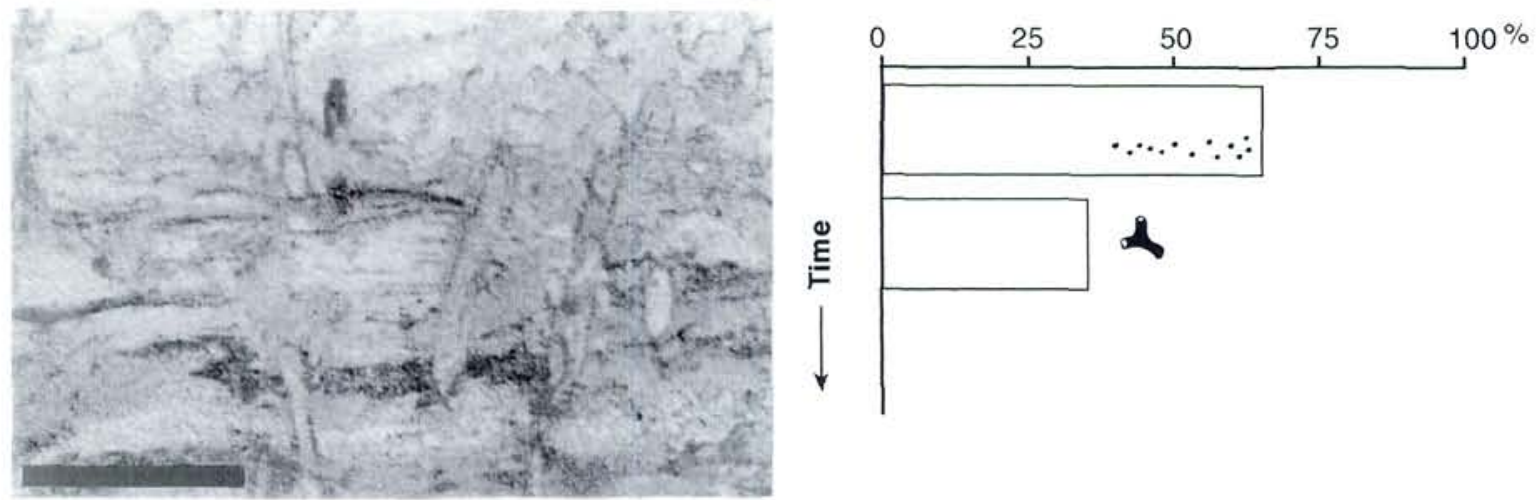

B
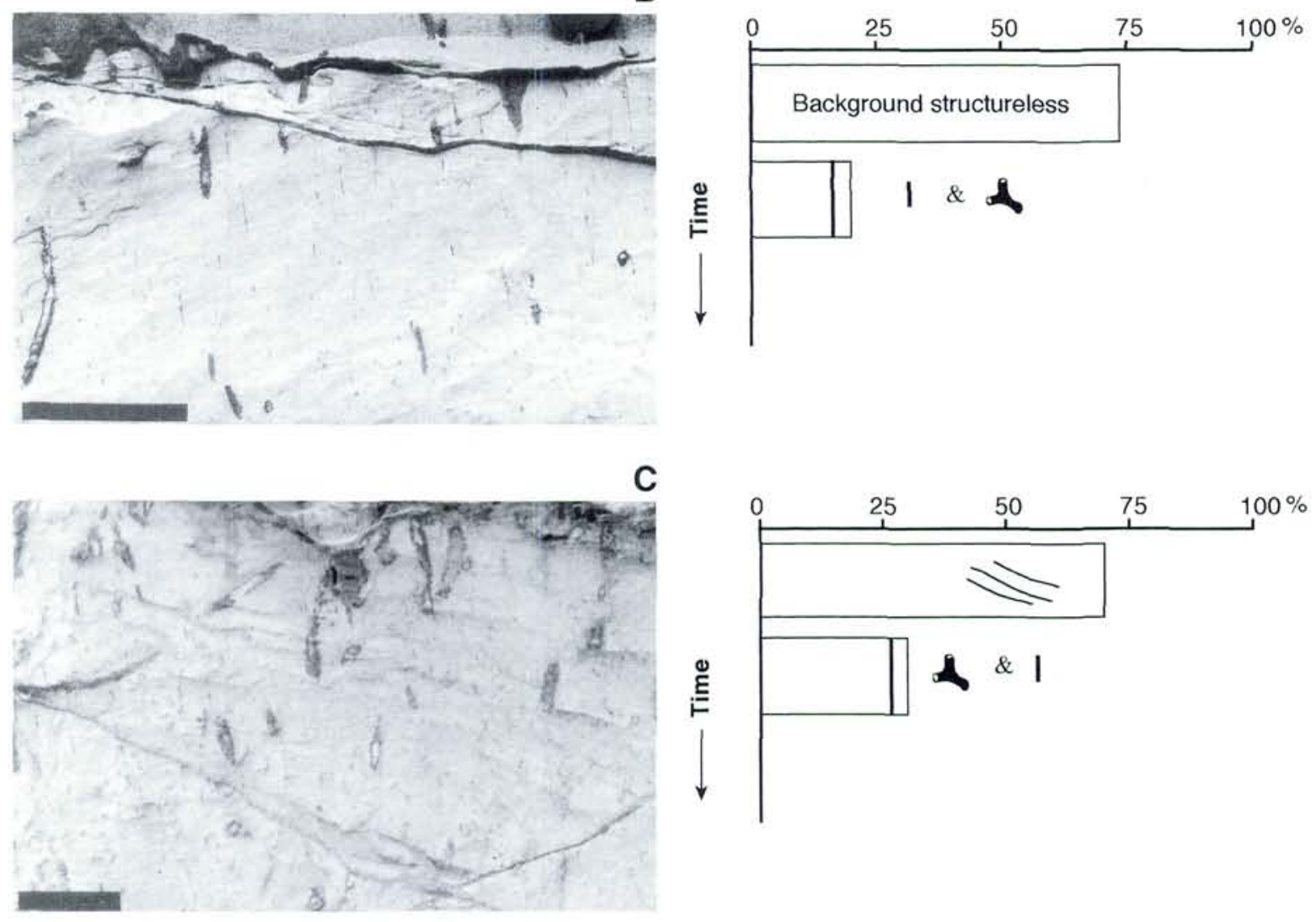

Fig. 9. Photographs of ichnofabrics and time sequence diagrams. A vertical line across a bar indicates that cross-cuttings between two ichnospecies have not been recognized or may not exist. A: Ichnofabric $2 \mathrm{c}$, lower part of unit E. Scale $5 \mathrm{~cm}$. B: Ichnofabric 3a, upper part of unit E. Scale $20 \mathrm{~cm}$; C: Ichnofabric 3b, lower part of unit F1. Scale $5 \mathrm{~cm}$. 
$1.3 \mathrm{~m}$ at the same horizons. Recent Ophiomorpha nodosa from the southeastern USA reach lengths of at least 3-5 m (Frey et al. 1978), but these have larger diameters than the Ophiomorpha nodosa from the Robbedale material.

Wall-linings consist of rounded pellets, apparently in a single layer, smoothed on the interior wall surface. The pellets consist of a more fine-grained sediment than the surrounding sand. The pellets have a darker colour and are slightly more resistant to wind erosion.

Two kinds of branching have been observed. One in which the main vertical shafts diverge into two nearly horizontal branches. Another in which the main shaft branches into two steeply inclined shafts. No upward branching has been observed.

The Ophiomorpha nodosa intersect each other. This may be unavoidable, owing to the high density of trace fossils. However, in units having lower density of Ophiomorpha nodosa, intersection is less common or absent.

Collapse structures, caused by overburden of the overlying sediment, occur at the boundary E/F1 (Fig. 10). Each collapse structure consists of a vertical series of down-warped laminae. The tendency to inclination of the laminae diminishes upward (cf. Asgaard \& Bromley 1974, Frey et al. 1978, Kamola 1984, NoeNygaard \& Surlyk 1988). The collapse structure is usually associated with a horizontal or oblique segment of Ophiomorpha nodosa.

\section{Skolithos linearis Haldeman 1840}

These simple trace fossils (Fig. 9B) are nearly vertical, unbranched, cylindrical burrows. In unit $\mathrm{E}$ the shafts are extremely slender, having diameters between 0.8 and $1.5 \mathrm{~mm}$. In the uppermost part of unit $\mathrm{E}$ the diameters are about $1 \mathrm{~mm}$. They are traceable vertically over distances of at least $28 \mathrm{~cm}$ in unit E. Variation in diameter is less in the uppermost part of that unit. The diameter of the individual trace fossil is always constant. In the Robbedale Formation this ichnotaxon has been observed by Gry (1968), Gravesen (1982), Gravesen et al. (1982), Noe-Nygaard \& Surlyk (1988) and Hamann (1989).

\section{Teichichnus rectus Seilacher 1955}

Generally Teichichnus rectus (Fig. 11A \& 11B) are very uniform in size, both within units and across boundaries. All specimens exhibit a retrusive spreite. Max. length, max. width and max. depth are respectively $24.5 \mathrm{~cm}, 2.6 \mathrm{~cm}$ and c. $2 \mathrm{~cm}$. The traces are preserved as positive reliefs on weathered surfaces.

Thalassinoides suevicus (Rieth 1932) forms 1 and 2 The morphology of the Thalassinoides suevicus forms 1 and 2 (Fig. 11), which are found in the clay-rich units C, D1 and D2, resembles that of the Ophiomorpha nodosa, except for lack of wall-lining.

Thalassinoides suevicus form 1 is filled with white

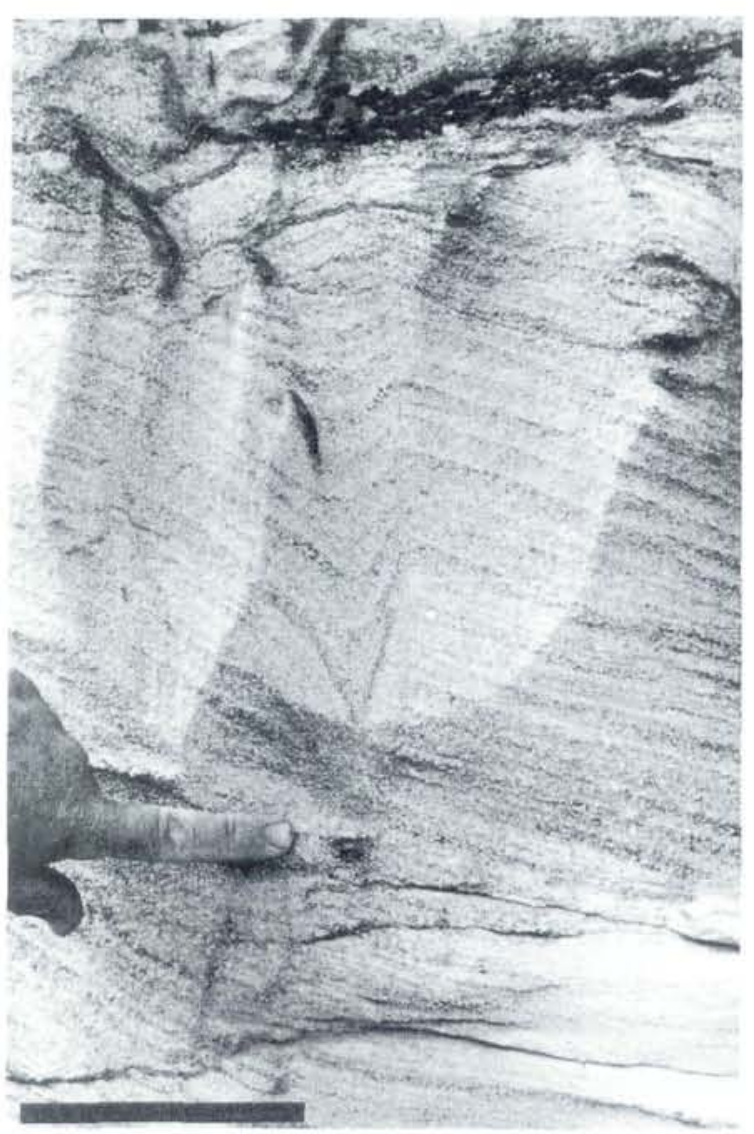

Fig. 10. Collapse structure in connection with Ophiomorpha nodosa, lowermost part of unit F1. Ophiomorpha nodosa at tip of finger. Scale $10 \mathrm{~cm}$.

sand. Diameters of Thalassinoides suevicus form 1 are $8-9 \mathrm{~mm}$, which overlaps the internal diameters of the Ophiomorpha. The transition of Ophiomorpha to Thalassinoides has been described by several authors including Bromley \& Frey (1974) and Frey et al. (1978: fig. 6). Such transitions occur in the Robbedale Formation at the Golf Course pit and at neighbouring localities, e.g. Skrædderbakken (R. G. Bromley, pers. com. 1992). Owing to this transition, and the morphological similarity of Ophiomorpha nodosa and Thalassi-noides suevicus form 1 , it is probable that the same tracemaker is responsible for the two ichnotaxa. The difference is probably an expression of the change in grain size and consistency between a clayey substrate and a substrate dominated by fine sand (Bromley \& Frey 1974; Ekdale, Bromley \& Pemberton 1984: 71, fig. 6-2; Asgaard \& Bromley 1989; Pollard, Goldring \& Buck 1993).

Thalassinoides suevicus form 2 has a fainter appearance than Thalassinoides suevicus form 1, and is filled with grey sand. The preferred orientation of segments is variable. The difference between the two forms is 
A
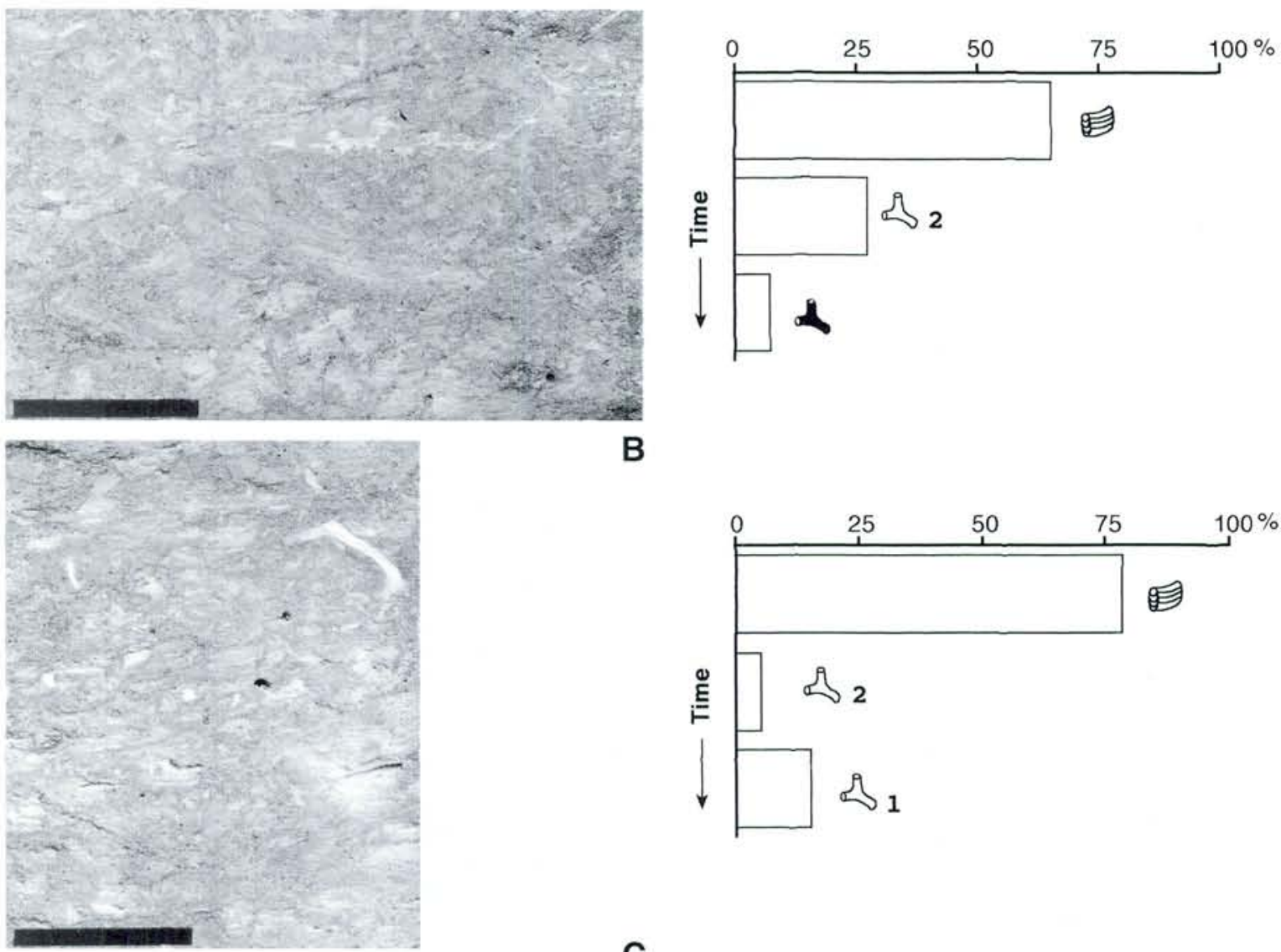

B
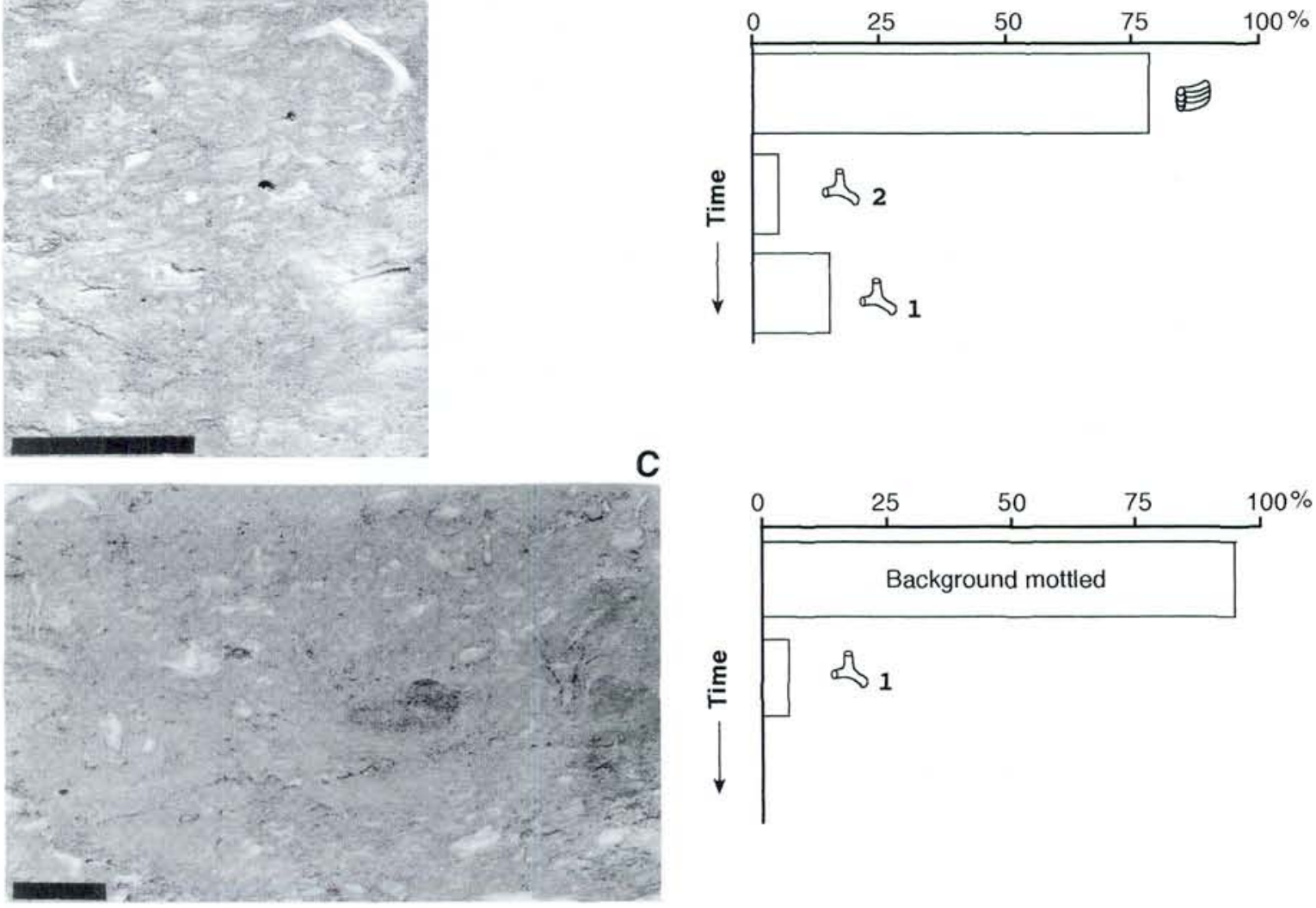

Fig. 11. Photographs of ichnofabrics and time sequence diagrams. A: Ichnofabric 4a, unit D2. Scale $10 \mathrm{~cm}$; B: Ichnofabric $4 \mathrm{~b}$, unit D1. Scale $10 \mathrm{~cm}$; C: Ichnofabric $5 \mathrm{a}$, unit C. Scale $10 \mathrm{~cm}$. 
subtle and therefore the ichnotaxa are considered as informal.

\section{Tiering of trace fossils}

The term tiering was suggested by Bottjer \& Ausich (1982) for vertical partitioning in a endobenthic community. Conichnus conosinus isp. $\mathrm{n}$. and Teichichnus rectus are shallow tier structures. Cylindrichnus isp. and Skolithos linearis are intermediate tier structures. Thalassinoides suevicus forms 1 and 2 seem to be intermediate to deep tier structures. Ophiomorpha nodosa is a deep tier structure. Several unit boundaries are cross-cut by Ophiomorpha nodosa (see below).

\section{Ichnofabrics}

Ekdale \& Bromley (1983: 110) defined the term ichnofabric as "those aspects of the texture and internal structure of the bed resulting from all phases of bioturbation". Distinctive types of ichnofabrics are recognised within each sedimentary unit (Fig. 3). Lateral variation is only minor. Each of these ichnofabrics is described by a time sequence diagram based on crosscutting relationships and amount of bioturbation (Figs $8,9 \& 11$ ). A closely similar version of this diagram, ichnofabric constituent diagram (ICD), has been presented by Taylor \& Goldring (1993) and Pollard et al. (1993). However, whereas those authors use a logarithmic scale for the horizontal axis, we use a natural scale, which provides a better visual impression of the ichnofabric. Another type of diagram, tiering bioturbation model, was presented by Bromley (1990: fig. 6.18). This diagram is not used because cross-cutting relationships of a trace fossil as Ophiomorpha nodosa often reflect time sequence of burrowing and not tier depth relationships. Associated ichnotaxa do not necessary reflect original tiering in an aggradational substrate (Pollard et al. 1993; J. Pollard, pers. com. 1996).

The seven-level scheme of bioturbation indices (BI) suggested by Taylor \& Goldring (1993) and with examples demonstrated by Pollard et al. (1993) is used to indicate the amount of bioturbation visible in each ichnofabric. BI 0 is zero bioturbation and BI 6 is $100 \%$ bioturbation. The scheme is similar to the semi-quantitative six-level scheme of ichnofabric indices (ii) established by Droser \& Bottjer (1986) and Bottjer \& Droser $(1991 ; 1994)$. The BI grades are used since they are based on verbal descriptions supported by percentage bioturbation values (see Taylor \& Goldring 1993: table 1). The verbal descriptions can only to some degree be followed because the amount of burrow overlap is not necessarily directly proportional to the amount of bioturbated sediment (see ichnofabric 3a below). In addition the visibility of trace fossils representing shallow tiers is rather poor, even in ichnofabrics of low BI. The visibility of trace fossils should therefore be used with caution to determine BI grades.

The amount of bioturbation for each ichnotaxon is described by using the terms sparse, common and abundant (Ekdale et al. 1984) instead of BI because of extremely poor visibility of shallow tiers. The same considerations concern the percentage bioturbation values indicated in the time sequence diagrams. Therefore the values must be considered as approximate.

Ichnofabric 1a (Fig. 8A): This ichnofabric occurs in the upper part of unit A. Background is structureless. $\mathrm{BI}$ is 2. Cylindrichnus isp. is very sparse and appears as elliptical structures. Ophiomorpha nodosa has thick linings and individual shafts tend to cluster in groups that radiate divergently downward. Density of Ophiomorpha nodosa increases upward from sparse to common. At the boundary A/COphiomorpha nodo$s a$ are truncated by erosion. At the northeastern end of the outcrop, where erosion at this contact was weak, Conichnus conosinus isp. $n$. structures truncate a large proportion of Ophiomorpha nodosa traces in unit A. Conichnus conosinus isp. $\mathrm{n}$. occurs with the groups of Ophiomorpha nodosa. Conichnus conosinus isp. $\mathrm{n}$. represents the uppermost preserved bioturbation tier.

Ichnofabric 2a (Fig. 8B): This ichnofabric is found in the lower part of unit $A$. The original primary layering forms the background. BI is 1-2. Cylindrichnus isp. is very sparse, appearing as elliptical structures.Ophiomorpha nodosa is not clustered and no preferred orientation has been observed. The wall-linings have variable thickness, and the roof-linings are especially thick.

Ichnofabric $2 \mathrm{~b}$ (Fig. 8C): This ichnofabric is found in the upper part of unit $\mathrm{F} 1$ and in unit $\mathrm{F} 2$. The original primary layering forms the background. BI is 2.Ophiomorpha nodosa is common. Ophiomorpha nodosa is much branched and the wall-linings are thick.

Ichnofabric 2c (Fig. 9A): This ichnofabric is found in the lower part of $\mathrm{E}$. The original primary layering forms the background. BI is 2-3. The density of Ophiomorpha nodosa decreases from abundant to sparse. Ophiomorpha nodosa is densely branched and the wall-linings are distinctly thinner than in ichnofabric $2 b$.

Ichnofabric 3a (Fig. 9B): This ichnofabric is found in the upper part of unit $E$. The original primary layering forms the background. BI is 2. Ophiomorpha nodo$s a$ is sparse and Skolithos linearis is common. The individuals of Skolithos linearis avoid cross-cutting each other (phobotaxis). No contacts between Skolithos linearis and Ophiomorpha nodosa have been observed. Ophiomorpha nodosa are dominately sub-vertically oriented. The wall-linings of Ophiomorpha nodosa are thick. Ophiomorpha nodosa from unit F1 crosses the boundary E/F1. Collapse structures in connection with upper parts of Ophiomorpha nodosa have been found at the boundary E/F1.

Ichnofabric 3b (Fig. 9C): This ichnofabric is found in the lower part of F1. The original primary layering 
makes up the background. BI is 2. Ophiomorpha nodosa is sparse.Ophiomorpha nodosa is distinctly less dominated by sub-vertical segments than in ichnofabric $2 \mathrm{~b}$ and wall linings are very thick. Skolithos linearis is common. Collapse structures may occur.

Ichnofabric 4a (Fig. 11A): This ichnofabric is found in unit D2. BI is 6 . The background is made up of common Teichichnus rectus, cut by sparse Thalassinoides suevicus form 2 and sparse Ophiomorpha nodosa. Ophiomorpha nodosa cuts Thalassinoides suevicus form 2. Teichichnus rectus are apparently preferentially orientated with their long axis NE-SW. No preferred orientation of Thalassinoides suevicus form 2 has been observed.Ophiomorpha nodosa is dominately sub-vertical and no branching has been found. Wall-linings are developed but they are not thick. Ophiomorpha nodosa crosses the upper boundary.

Ichnofabric 4b (Fig. 11B): This ichnofabric is found in unit D1. BI is 6 . The background is made up of abundant Teichichnus rectus, cut by sparse Thalassinoides suevicus form 2 and sparse Thalassinoides suevicus form 1 . Cross-cutting relationships are unambiguous. Thalassinoides suevicus form 1 cuts Thalassinoides suevicus form 2. Thalassinoides suevicus form 2 is mostly obliquely oriented. Teichichnus rectus are apparently preferentially orientated with their long axis NE-SW. The orientation of Thalassinoides suevicus form 1 is oblique to vertical. The gradual boundary D1/D2 is crossed by all three trace fossils. In contrast to $4 \mathrm{a}$, Ophiomorpha nodosa is lacking.

Ichnofabric 5a (Fig. 11C): This ichnofabric is found in unit $\mathrm{C}$. $\mathrm{BI}$ is 6 . The background is mottled by bioturbation. Thalassinoides suevicus form 1 is sporadically distributed and randomly oriented. No branching is observed. In contrast to the overlying $4 \mathrm{a}$ and $4 \mathrm{~b}$, Teichichnus rectus is absent. Thalassinoides suevicus form 1 crosses the boundary C/D1.

\section{Ichnological discussion}

The use of ichnofabrics instead of ichnofacies typically gives a higher degree of resolution (Goldring 1993). In this case there is a higher number of ichnofabrics compared with the potential number of ichnofacies. In the following, the ichnofabrics and their chronology are discussed in terms of environmental interpretation.

Ichnofabrics 2a and 1a: Cylindrichnus occurs typically in sandy sediment deposited in marine protected shoreface and open shoreface (McCarthy 1979). Ophiomorpha occurs typically in shallow-marine sandy facies (Ekdale 1992; Merrill 1984; Pollard et al. 1993). In some cases Ophiomorpha has been found in sediments representing nonmarine environments (Merrill 1984; Stewart 1978), but according to Goldring \& Pollard (1995), Stewart (1978) was mistaken.

The upward increase of Ophiomorpha nodosa may indicate a lower sedimentation rate in the top of unit A. This could ultimately have led to a sedimentation stop at the upper boundary, but the sedimentological data do not indicate any changes in depositional rate until at the boundary A/C. As the primary structures have been obliterated by bioturbation, other abiotic factors (e.g. salinity, temperature, etc.) may have caused an increase of Ophiomorpha nodosa. The presence of the Conichnus conosinus isp. n., which is clearly related to the Ophiomorpha nodosa, indicates that after the erosion of unit A the surface was colonised again. The variable wall-linings of Ophiomorpha nodosa in the lower part of the unit may indicate that the substrate was relatively stable.

Ichnofabric 5a: Thalassinoides is most common in shallow marine settings (Ekdale 1992). The white fill of Thalassinoides suevicus form 1 indicates that the burrow system was open when the sedimentation of the overlying white sand was initiated. Consequently the Thalassinoides suevicus form 1 is not necessarily contemporary with the deposition of the muddy sediment but instead represents colonization of the C/D1 surface or maybe a surface further above.

Ichnofabrics $4 \mathrm{~b}$ and $4 \mathrm{a}$ : The gradual increase in the grain size of the sediment through units D1 and D2 caused a transition in sediment consistency from relatively stable to unstable, thus inducing the transition from Thalassinoides suevicus form 1 to Ophiomorpha nodosa. This supports Ekdale (1992) who stated that the distribution of Ophiomorpha and Thalassinoides is influenced by substrate conditions rather than by bathymetry. The preferred orientation of Teichichnus rectus could be explained as a response to palaeoslope or predominant bottom current-direction.

Ichnofabrics $2 c$ and 3a: The abrupt decrease in abundance of Ophiomorpha nodosa at the lower part of unit $E$ could indicate that an increased sedimentation rate caused a more stressed environment. The introduction of Skolithos linearis may indicate that a further increase in energy conditions has occurred at the top of the unit. The fact that $O$ phiomorpha nodosa consists mainly of shafts and co-occurs with Skolithos linearis indicates, under the assumption that they were contemporary, that it was an assemblage of opportunists (Bromley 1990: 215). The dominance of Ophiomorpha nodosa shafts is typical of high-energy settings (Frey et al. 1978; Kamola 1984). Compared with Upper Cretaceous marine deposits described by Howard \& Frey (1984) such settings could be lower foreshore, foreshoreshoreface transition and upper shoreface. Ophiomorpha nodosa and Skolithos isp. have been found together in sediment deposited in a lower foreshore-upper shoreface environment (Curran 1985). The collapse structures in connection with Ophiomorpha nodosa indicate that the substrate was unstable when the burrows were constructed, or at least before they were filled with sediment. Kamola (1984) found Ophiomorpha nodosa, Skolithos and collapse structures as parts of a Cretaceous channel-fill assemblage. A similar as- 
semblage may be found in modern high-energy marine environments (Kamola 1984).

Ichnofabrics $3 \mathrm{~b}$ and $2 \mathrm{~b}$ : In the transition from ichnofabric $3 b$ to $2 b$, the disappearance of both Skolithos linearis and the collapse structures may indicate a lowering in energy level. Some specimens of the Ophiomorpha nodosa in unit $\mathrm{F} 1$ probably originated in strata above unit F2. Though thickness of wall-linings is not always related to sediment stability (e.g. Frey et al. 1978: 207), the thick wall-linings and the collapse structures of the Ophiomorpha nodosa may indicate that the sediment was unstable.

The ichnofabrics presented in this paper more or less resemble ichnofabrics recorded by Pollard et al. (1993) in shallow-water facies. Especially their ichnofabric 3 (Ophiomorpha with primary lamination), which they principally based on deposits interpreted as estuarine sedimentation, resembles our ichnofabrics with $O p$ hiomorpha nodosa. Structures similar to the collapse structures in the Robbedale Formation have been interpreted as caused by up-down movements of tidal watertable within the sediment in intertidal sediments (cf. Bromley 1990: fig. 7.1). In the studied section of the Robbedale Formation there is no evidence of any primary sedimentary structures indicating tidal influence.

\section{Conclusion}

At a sand quarry adjacent to the Rønne Golf Course a section of the Robbedale Formation, consisting of $\emptyset$ sterborg Member and Langbjerg Member, has been divided into depositional units from $A$ to $F$ representing four sedimentary facies. These are interpreted as comprising part of an aggrading to prograding clastic wedge. Based on sedimentary features (grain size, sorting and scarce physical structures) the depositional environment is interpreted as lower to upper shoreface in a wave dominated barred coastal environment.

Nine distinct types of ichnofabrics have been found in this section. Distinction between the ichnofabrics is primarily based on characters such as ichnotaxa, crosscutting relationships (time sequence), orientation (attitude) of trace-fossil segments and occurrence and thickness of wall-lining. The distribution of ichnofabrics depends largely upon lithology as an indication of substrate consistency. Ichnofabrics may indicate that at least parts of the deposits were formed in a highenergy environment, perhaps marine lower to upper shoreface setting.

Conichnus conosinus isp. n. consists of sub-conical depressions having two main components: an upper, broad, dish-shaped depression and a steeply inclined cone in the central part of the trace. The dish-shaped upper depression tends to be prolonged as an oval in one direction, making the trace bilaterally symmetrical. The trace fossil resembles the ichnogenus Pisci- chnus, but is classified as Conichnus because of its generally conical appearance as opposed to the dishshape of Piscichnus Feibel 1987. Ethologically, Conichnus conosinus isp. $\mathrm{n}$. probably represents a fodinichnion.

\section{Dansk sammendrag}

En blotning af Robbedale Formationen fra Nedre Kridt ved Rønne Golfbane, Bornholm, har tilladt et mere detaljeret ichnologisk studie end hidtidigt. Ud fra sedimentologiske evidenser tolkes aflejringsmiljøet til at have været et aggraderende til prograderende bølgedomineret kystmiljø med barrer (hovedsageligt nedre til øvre strandplan).

Følgende sporfossiler er fundet: Conichnus conosinus isp. n., Cylindrichnus isp.,Ophiomorpha nodosa, Skolithos linearis, Teichichnus rectus og Thalassinoides suevicus formerne 1 og 2 . Disse syv sporfossiler indgår i ni "ichnofabrics". Disse "ichnofabrics" synes at indikere en marin oprindelse. De er tæt relateret til sedimentære facies. Skelnen mellem "ichnofabrics" er hovedsageligt baseret på karakterer som arter af sporfossiler, skæringsrelationer (tidssekvens), orientering af sporfossilers segmenter og forekomst og tykkelse af vagbeklædning. Ved at anvende "ichnofabrics" opnåes, at flere data inkorporeres i dataindsamling og tolkning, og at en højere opløsning fås, end hvis "ichnofacies" var anvendt. Fordelingen af "ichnofabrics" synes primært at afhænge af lithologi og substratets konsistens.

Associeret med Ophiomorpha nodosa ved en horisont findes et hyppigt forekommende sporfossil, som har en vis lighed med "rokkehuller". Den tilgængelige nomenklatur for sådanne strukturer diskuteres. Sporfossilet navngives Conichnus conosinus isp. n. Ethologisk kan det tolkes som dannet ved ædeadfærd, der involverede en udnyttelse af organisk materiale inkorporeret i vægbeklædningen hos Ophiomorpha nodosa.

\section{Acknowledgements}

Special thanks go to A. A. Ekdale (University of Utah, USA), R. G. Bromley (University of Copenhagen, Denmark) and J. Gérard (Elf Aquitaine Production, France) for their invaluable field assistance and advice; to R. G. Bromley also for very useful comments and discussions on early drafts of the manuscript. R. Goldring (University of Reading, UK) and J. Pollard (University of Manchester, UK) reviewed a draft of the manuscript and offered very helpful suggestions. G. K. Pedersen (University of Copenhagen, Denmark) is thanked for her very constructive review of the submitted manuscript. J. Aagaard (University of Copenhagen, Denmark) helped with photographic work and 
H. Egelund (University of Copenhagen, Denmark) helped with drawing.

\section{References}

Allen, J. R. L. 1982: Storm sequences in shallow water. In Allen, J. R. L. (ed.) Sedimentary studies, their character and basis, II, 471-506, Developments in sedimentology 30. New York: Elsevier.

Archer, A. W. 1984: Preservational control of trace-fossil assemblages: Middle Mississippian carbonates of southcentral Indiana. Journal of Paleontology 58, 285-297.

Asgaard, U. \& Bromley, R. G. 1974: Sporfossiler fra den Mellemmiocæne transgression i Søby-Fasterholt området. Dansk geologisk Forening, Årsskrift for 1973, 11-19.

Asgaard, U. \& Bromley, R. G. 1989: Influence of substrate on trace fossil distribution. 28th International Geological Congress, Washington, D.C., July 9-19 1989, 28, 58.

Bottjer, D. J. \& Ausich, W. I. 1982: Tiering and sampling requirements in paleocommunity reconstruction. Proceedings of the Third North American Paleontologic Convention 1, 57-59.

Bottjer, D. J. \& Droser, M. L. 1991: Ichnofabric and basin analysis. Palaios 6, 199-205.

Bottjer, D. J. \& Droser, M. L. 1994: The history of Phanerozoic bioturbation. In Donovan, S. K. (ed.) The palaeobiology of trace fossils, 155-176. Chichester: John Wiley \& Sons.

Bromley, R. G. 1979: Field meeting in southern Scandinavia 18-28 September 1975. Proceedings of Geologists' Association 90, 181-191.

Bromley, R. G. 1990: Trace fossils: biology and taphonomy. 280 pp. London: Unwin Hyman.

Bromley, R. G. 1996: Trace fossils: biology, taphonomy and applications. 2nd edition, 361 pp. London: Chapman \& Hall.

Bromley, R. G. \& Frey, R. W. 1974: Redescription of the trace fossil Gyrolithes and taxonomic evaluation of Thalassinoides, Ophiomorpha and Spongeliomorpha. Bulletin of the Geological Society of Denmark 23, 311-335.

Christensen, O. B. 1974: Marine communications through the Danish Embayment during uppermost Jurassic and Lowermost Cretaceous. Geoscience and Man 6, 99-115.

Clifton, H. E. 1981: Progradational sequences in Miocene shoreline deposits, southeastern Caliente Range, California. Journal of Sedimentary Petrology 51, 165-184.

Cook, D. O. 1971: Depressions in shallow marine sediment made by benthic fish. Journal of Sedimentary Petrology $41,577-602$.

Curran, H. A. 1985: The trace fossil assemblage of a Cretaceous nearshore environment: Englishtown Formation of Delaware, U.S.A. In Curran, H. A. (ed.) Biogenic structures: their use in interpreting depositional environments. Society of Economic Paleontologists and Mineralogists. Special Publication 35, 261-276

Doré, A. G. 1991: The structural foundation and evolution of Mesozoic seaways between Europe and the Arctic. Palaeogeography, Palaeoclimatology, Palaeoecology 87 , $441-492$.

Droser, M. L. \& Bottjer, D. J. 1986: A semiquantitative field classification of ichnofabric. Journal of Sedimentary Petrology 56, 558-559.
Ekdale, A. A. 1992: Muckraking and mudslinging: the joys of deposit-feeding. In Maples, C. G. \& West, R. R. (eds) Trace fossils, 145-171. Paleontological Society, Short courses in Paleontology 5. Tennessee, Knoxville.

Ekdale, A. A. \& Bromley, R. G. 1983: Trace fossils and ichnofabric in the Kjølby Gaard Marl, uppermost Cretaceous, Denmark. Bulletin of the Geological Society of Denmark 31, 107-119.

Ekdale, A. A., Bromley, R. G. \& Pemberton, S. G. 1984: Ichnology: trace fossils in sedimentology and stratigraphy. Society of Economic Paleontologists and Mineralogists, Short Course 15, 317 pp.

Ekdale, A. A. \& Lewis, D. W. 1991: Trace fossils and paleoenvironmental control of ichnofacies in a late Quaternary gravel and loess fan delta complex, New Zealand. Palaeogeography, Palaeoclimatology, Palaeoecology 81, 253279.

Farrow, G. E. 1975: Techniques for the study of fossil and recent traces. In Frey, R. W. (ed.) The study of trace fossils, 537-554. New York: Springer-Verlag.

Feibel, C. S. 1987: Fossil fish nests from the Koobi Fora Formation (Plio-Pleistocene) of northern Kenya. Journal of Paleontology 61, 130-134.

Fredningsstyrelsen 1986: Havbundsunders $\emptyset$ gelser. Råstoffer og fredningsinteresser. Oversigt, Bornholm. 40 pp. København: Miljøministeriet.

Frey, R. W., Howard, J. D. \& Pryor, W. A. 1978: Ophiomorpha: its morphologic, taxonomic, and environmental significance. Palaeogeography, Palaeoclimatology, Palaeoecology 23, 199-229.

Goldring, R. 1993: Ichnofacies and facies interpretation. Palaios 8, 403-405.

Goldring, R. \& Pollard, J. E. 1995: A re-evaluation of Ophiomorpha burrows in the Wealden Group (Lower Cretaceous) of southern England. Cretaceous Research $16,665-680$.

Gravesen, P. 1982: Lower Cretaceous sedimentation and basin extension on Bornholm, Denmark. Geological Survey of Denmark, Yearbook 1981, 73-99.

Gravesen, P. 1986: Petrography of the quartz sand deposits of the Lower Cretaceous of Bornholm, Denmark. Geological Survey of Denmark A10, $24 \mathrm{pp}$.

Gravesen, P., Rolle, F. \& Surlyk, F. 1982: Lithostratigraphy and sedimentary evolution of the Triassic, Jurassic and Lower Cretaceous of Bornholm, Denmark. Geological Survey of Denmark B7, $51 \mathrm{pp}$.

Gregory, M. R. 1991: New trace fossils from the Miocene of Northland, New Zealand: Rorschachichnus amoeba and Piscichnus waitemata. Ichnos 1, 195-205.

Gry, H. 1968: Callianassagange og Skolithosror i Robbedaleformationen. Meddelelser fra Dansk Geologisk Forening 18, 205-212.

Haldeman, S. S. 1840: Supplement to number one of "A monograph of the Limniades, or freshwater univalve shells of North America", containing descriptions of apparently new animals in different classes, and the names and characters of the subgenera in Paludina and Anculosa. $3 \mathrm{pp}$. Philadelphia: ?private publication.

Hamann, N. E. 1989: Bornholms Mesozoikum. Varv, København $3,1-104$.

Howard, J. D. 1966: Characteristic trace fossils in Upper Cretaceous sandstones of the Book Cliffs and Wasatch Plateau. Utah Geological and Mineralogical Survey Bulletin $80,35-53$.

Howard, J. D. \& Frey, R. W. 1984: Characteristic trace fos- 
sils in nearshore to offshore sequences, Upper Cretaceous of east-central Utah. Canadian Journal of Earth Sciences $21,200-219$.

Hunter, R.E., Clifton, H. E. \& Phillips, R. L. 1979: Depositional processes, sedimentary structures, and predicted vertical sequences in barred nearshore systems, southern Oregon coast. Journal of Sedimentary Petrology 49, 711726.

Inman, D. L., Ewing, D. C. \& Corliss, J. B. 1966: Coastal sand dunes of Guerro Negro, Baja California, Mexico. Geological Society of America Bulletin 77, 787-802.

Japsen, P. 1993: Influence of lithology and Neogene uplift on seismic velocities in Denmark: Implications for depth conversions of maps. The American Association of Petroleum Geologists Bulletin 77, 194-211.

Johnson, T. C., Halfman, J. D., Busch, W. H. \& Flood, R. D. 1984: Effects of bottom currents and fish on sedimentation in a deep-water, lacustrine environment. Geological Society of America Bulletin 95, 1425-1436.

Jux, U. \& Strauch, F. 1968: Ophiomorpha Lundgren 1891 aus dem Mesozoikum von Bornholm. Meddelelser fra Dansk Geologisk Forening 18, 213-219.

Kamola, D. L. 1984: Trace fossils from marginal-marine facies of the Spring Canyon Member, Blackhawk Formation (Upper Cretaceous), east-central Utah. Journal of Paleontology 58, 529-541.

Karplus, I., Szlep, R. \& Tsurnamal, M. 1974: The burrows of alpheid shrimp associated with gobiid fish in the northern Red Sea. Marine Biology 24, 259-268.

Knaust, D. \& Langbein, R. 1995: Pot casts in the Upper Muschelkalk (Middle Triassic) of Weimar/Thuringia composition, microfabrics and diagenesis. Facies, Erlangen 33, 151-165.

Komar, P. D. 1976: Beach processes and sedimentation. 429 pp. Englewood Cliffs, N. J.: Prentice-Hall.

Lundgren, B. 1891: Studier öfver fossilförande lösa block. Geologiska Föreningens i Stockholm, Förhandlingar 13, 111-121.

Mauviel, A., Juniper, S. K. \& Sibuet, M. 1987: Discovery of an enteropneust associated with a mound-burrows trace in the deep sea: ecological and geochemical implications. Deep-Sea Research 34, 329-335.

McCarthy, B. 1979: Trace fossils from a Permian shorefaceforeshore environment, Eastern Australia. Journal of Paleontology 53, 345-366.

Merrill, R. D. 1984: Ophiomorpha and other nonmarine trace fossils from the Eocene Ione Formation, California. Journal of Paleontology 58, 542-549.

Miller, M. F. \& Myrick, J. L. 1992: Population fluctuations and distributional controls of Callianassa californiensis: effect on the sedimentary record. Palaios 7, 621-625.

Myannil, R. M. 1966: O vertikalnykh norkakh zaryvaniya v Ordovikskikh izvestiyakakh Pribaltiki. In Organizm i sreda $v$ geologischeskom proshlom, 200-207. Akademiya Nauk SSSR, Paleontologicheskiy Institut. [Notes on the vertical burrowing in the Ordovician limestones of Pribaltica. In Organism and environment in the geologic past, 200-207. USSR Academy of Science, Palaeontological Institute].

Noe-Nygaard, N. \& Surlyk, F. 1988: Washover fan and brackish bay sedimentation in the Berriasian-Valangian of Bornholm, Denmark. Sedimentology 35, 197-217.

Noe-Nygaard, N., Surlyk, F. \& Piasecki, S. 1987: Bivalve mass mortality caused by toxic dinoflagellate blooms in a Berriasian-Valanginian Lagoon, Bornholm, Denmark. Palaios 2, 263-273.

Norling, E. 1981: Upper Jurassic and Lower Cretaceous geology of Sweden. Geologiska Föreningens i Stockholm Förhandlingar 103, 253-269.

Nummedal, D. \& Swift, J. P. 1987: Transgressive stratigraphy at sequencebounding unconformities: Some principles derived from Holocene and Cretaceous examples. In Nummedal, D., Pilkey, O. H. \& Howard, J. D. (eds) Sealevel fluctuations and coastal evolution. Society of Economic Paleontologists and Mineralogists, Special Publication 41, 241-260.

Pemberton, S. G., Frey, R. W. \& Bromley, R. G. 1988: The ichnotaxonomy of Conostichus and other plug-shaped ichnofossils. Canada Journal of Earth Science 25, 866892.

Piasecki, S. 1984: Dinoflagellate cyst stratigraphy of the Lower Cretaceous Jydegărd Formation, Bornholm, Denmark. Bulletin of the Geological Society of Denmark 32, 145-161.

Pollard, J. E., Goldring, R. \& Buck, S. G. 1993: Ichnofabrics containing Ophiomorpha: significance in shallow-water facies interpretation. Journal of the Geological Society, London 150, 149-164.

Rieth, A. 1932: Neue Funde spongeliomorpher Fucoiden aus dem Jura Schwabens. Geologische und Palæontologische Abhandlungen, Jena 19, 257-294.

Seilacher, A. 1955: Spuren und Fazies im Unterkambrium. In Schindewolf, O. H. \& Seilacher, A. (eds) Beiträge zur Kenntnis des Kambriums in der Salt Range (Pakistan). Akademie der Wissenschaften und der Litteratur, Abhandlungen der mathematisch-naturwissenschaftlichen Klasse, Mainz 10, 117-143.

Stewart, D. J. 1978: Ophiomorpha: a marine indicator?. Proceedings of the Geologists Association 89, 33-41.

Surlyk, F. 1980: Denmark. In Geology of the European countries, Denmark, Finland, Iceland, Norway, Sweden, 1-50. 26th International Geological Congress, Paris, July 7-17, 1980. Paris: Dunod.

Swift, D. J. P. \& Thome, J. A. 1991: Sedimentation on continental margins, I: a generalmodel for shelf sedimentation. In Swift, D. J. P., Oertel, G. F., Tillman, R. N. \& Thorne, J. A. (eds) Shelf sand and sandstone bodies: geometry, facies and sequence stratigraphy, Special Publication of the International Association of Sedimentologists 14, 3-31. Oxford: Blackwell Scientific.

Taylor, A. M. \& Goldring, R. 1993: Description and analysis of bioturbation and ichnofabric. Journal of the Geological Society, London 150, 141-148.

Willers, W. B. 1981: Trout Biology. 206 pp. Madison: University of Wisconsin Press.

Ziegler, P. A. 1987: Late Cretaceous and Cenozoic intraplate compressional deformations in the Alpine foreland - a geodynamic model. Tectonophyscis $137,389-420$. 